\title{
Distribution of Roseobacter RCA and SAR11 lineages in the North Sea and characteristics of an abundant RCA isolate
}

\author{
Helge-Ansgar Giebel, Daniela Kalhoefer, Andreas Lemke, Sebastian Thole, \\ Renate Gahl-Janssen, Meinhard Simon and Thorsten Brinkhoff \\ Institute for Chemistry and Biology of the Marine Environment (ICBM), University of Oldenburg, \\ Oldenburg, Germany
}

\begin{abstract}
The Roseobacter group and SAR11 clade constitute high proportions of the marine bacterioplankton, but only scarce information exists on the abundance of distinct populations of either lineage. Therefore, we quantified the abundance of the largest cluster of the Roseobacter group, the RCA (Roseobacter clade affiliated) cluster together with the SAR11 clade by quantitative PCR in the southern and eastern North Sea. The RCA cluster constituted up to 15 and $21 \%$ of total bacterial $16 S$ ribosomal RNA (rRNA) genes in September 2005 and May 2006, respectively. At a few stations, the RCA cluster exceeded the SAR11 clade, whereas at most stations, SAR11 constituted higher fractions with maxima of $37 \%$. In most samples, only one RCA ribotype was detected. RCA abundance was positively correlated with phaeopigments, chlorophyll, dissolved and particulate organic carbon (POC), turnover rates of dissolved free amino acids (DFAAs), temperature, and negatively correlated with salinity. The SAR11 clade was only correlated with POC (negatively, May) and with DFAA turnover rates (positively, September). An abundant RCA strain, 'Candidatus Planktomarina temperata', was isolated from the southern North Sea. This strain has an identical 16S rRNA gene sequence to the dominant RCA ribotype. Detection of the pufM gene, coding for a subunit of the reaction center of bacteriochlorophyll $a$, indicates the potential of the isolate for aerobic anoxygenic photosynthesis. Our study shows that a distinct population of the RCA cluster constitutes an abundant bacterioplankton group in a neritic sea of the temperate zone and indicates that this population has an important role during decaying phytoplankton blooms.
\end{abstract}

The ISME Journal (2011) 5, 8-19; doi:10.1038/ismej.2010.87; published online 1 July 2010

Subject Category: microbial population and community ecology

Keywords: marine bacteria; Roseobacter, RCA; SAR11; North Sea; quantitative PCR

\section{Introduction}

At present, it is well established that mainly Alphaproteobacteria and Gammaproteobacteria, as well as Sphingobacteria and Flavobacteria constitute (photo)heterotrophic bacterioplankton communities in near-surface marine pelagic environments (Morris et al., 2005; Fuhrman et al., 2006; AlonsoSáez et al., 2007; Malmstrom et al., 2007; West et al., 2008; Alonso-Gutiérrez et al., 2009; Giebel et al., 2009). Prominent components include the SAR11, Roseobacter and SAR86 clades and the OM60/NOR5 cluster. However, still little is known about the

Correspondence: M Simon, Institute for Chemistry and Biology of the Marine Environment (ICBM), University of Oldenburg, D-26111 Oldenburg, Germany.

E-mail: m.simon@icbm.de

This work was supported by grants from Deutsche Forschungsgemeinschaft (DFG) within the Special Priority Program on Antarctic Research and within the research unit BioGeoChemistry of Tidal Flats (FG-432, TP 5).

Received 24 February 2010; revised 18 May 2010; accepted 19 May 2010; published online 1 July 2010 physiological properties of these groups, mainly because in most cases, no representative isolates are available and if they are, physiological and gene expression studies are scarce for various reasons, including that organisms are often difficult to grow (Giovannoni and Stingl, 2005, 2007).

A few strains of prominent phylogenetic lineages of the (photo)heterotrophic marine bacterioplankton have been isolated, for example, 'Candidatus Pelagibacter ubique' of the SAR11 clade (Rappé et al., 2002) and Congregibacter litoralis strain KT71 of the OM60/Nor5 cluster (Fuchs et al., 2007). The genomes and some physiological and genetic traits of these isolates have been analyzed (Giovannoni et al., 2005; Sowell et al., 2008; Tripp et al., 2008). One strain of the RCA (Roseobacter clade affiliated, Selje et al., 2004) cluster has been isolated, which exhibits close interactions with a dinoflagellate (Mayali et al., 2008), but no other clues for its biogeochemical role are known.

The North Sea is a typical shelf sea of the temperate zone. It is subdivided into a southern region with large intertidal flat areas, a central and a 
northern part. Depth does not exceed 50-100 m, except close to the Norwegian coast where it reaches $>200 \mathrm{~m}$ (Eisma, 1987). The composition of the bacterioplankton of the North Sea has been studied mainly in the southern part, addressing richness, evenness, seasonal and interannual variations and controls by various biological and environmental factors (Eilers et al., 2000, 2001; Gerdts et al., 2004; Reinthaler et al., 2005; Alderkamp et al., 2006; Rink et al., 2007; Sapp et al., 2007; Yan et al., 2009). These studies showed that the bacterioplankton is composed of phylogenetic lineages, which are also found in other marine pelagic ecosystems (see above). The RCA cluster with a sequence similarity of the 16S ribosomal RNA (rRNA) gene of $>98 \%$ was identified as a prominent component of the bacterioplankton in the southern North Sea (Selje et al., 2004). The only study in the northern North Sea has been carried out during an Emiliana huxleyi bloom (Zubkov et al., 2001, 2002), showing that the above-mentioned major phylogenetic groups constituted the bacterioplankton community to a great extent and that one phylotype of the Roseobacter group dominated the consumption of dimethylsulfonium propionate.

The aim of this study was to assess the abundance of the RCA cluster in the North Sea in two contrasting seasons in the context of environmental and biological properties and in relation to the SAR11 clade, the most abundant bacterioplankton clade in the oceans (Morris et al., 2002) and in the North Sea (Alonso and Pernthaler, 2006). Therefore, both bacterioplankton groups were quantified together with bacterioplankton biomass production, turnover rates of dissolved free amino acids (DFAAs) and chlorophyll on a transect from the German Bight to the Norwegian trench in September 2005 and May 2006. Furthermore, we isolated and characterized a strain of the RCA cluster from the southern North Sea to reveal the basic traits of these organisms.

\section{Materials and methods}

Study area and sampling

Samples were collected during two cruises with RV Heincke in the North Sea along a transect from the Weser estuary at $\sim 54$ to $58^{\circ} \mathrm{N}$ in Norwegian coastal waters in September 2005 (Sep05, HE-238) and to $59^{\circ} \mathrm{N}$ in May 2006 (May06, HE-249, Figure 1, Supplementary Table S1). Samples were collected in 51 Niskin bottles mounted on a rosette (Hydrobios, Kiel, Germany). Conductivity, temperature and depth profiles were measured at each station using a conductivity, temperature and depth sensor (OTS 1500, Meereselektronik, Kiel, Germany). Subsamples were immediately withdrawn from the bottles and further processed for various measurements (see below).

Biogeochemical and microbial parameters

Subsamples for chlorophyll $a$ (Chl $a$ ) and phaeopigments were filtered onto GF/F filters (Whatman,
Maidstone, UK, $47 \mathrm{~mm}$ diameter), immediately wrapped in aluminum foil and kept frozen at $-20^{\circ} \mathrm{C}$ until further analysis in the laboratory within 2 weeks. Filters were mechanically chopped and extracted in hot ethanol $\left(75^{\circ} \mathrm{C}\right)$ for $1 \mathrm{~h}$ in the dark. Concentrations of Chl $a$ and phaeopigments were determined spectrophotometrically and calculated according to Nusch (1999).

Subsamples for the analysis of suspended particulate matter (SPM), particulate organic matter and particulate organic carbon (POC) were filtered onto precombusted $\left(2 \mathrm{~h}, 450^{\circ} \mathrm{C}\right)$ and preweighed $\mathrm{GF} / \mathrm{F}$ filters (Whatman). Filters were rinsed with distilled water to remove salt and kept frozen at $-20^{\circ} \mathrm{C}$ until analysis as described in the study by Lunau et al. (2006). Concentrations of dissolved organic carbon (DOC) were determined as described in the study by Dellwig et al. (2007). Concentrations of DFAA were analyzed by high-performance liquid chromatography after ortho-phthaldialdehyde precolumn derivatization as described in the study by Lunau et al. (2006). Subsamples for DFAA analysis were filtered on board through $0.2 \mu \mathrm{m}$ low protein-binding filters (Tuffrin Acrodisc, Whatman) and kept frozen at $-20{ }^{\circ} \mathrm{C}$ until analysis.

Bacterioplankton cell numbers were determined by epifluorescence microscopy after SybrGreen I staining as described previously (Lunau et al., 2005). Subsamples were preserved with glutardialdehyde (final concentration $2 \%$ ) and stored at $-80^{\circ} \mathrm{C}$ until further analysis.

Rates of bacterial production (BP) were determined by the incorporation of ${ }^{14} \mathrm{C}$-leucine (Simon and Azam, 1989). Triplicate $5 \mathrm{ml}$ subsamples and a formalin-killed control were incubated with ${ }^{14} \mathrm{C}$-leucine $\left(10.8 \mathrm{GBq} \mathrm{mmol}^{-1}\right.$, Hartmann Analytic, Braunschweig, Germany) at a final concentration of $20 \mathrm{nM}$ in the dark at in situ temperature for $1 \mathrm{~h}$ and further processed as described previously (Lunau et al., 2006). Biomass production was calculated using a conversation factor of $3.05 \mathrm{~kg} \mathrm{C} \mathrm{(mol}$ leucine $)^{-1}$ according to Simon and Azam (1989).

Turnover rate constants of DFAA were determined by measuring the incorporation of a mixture of $16{ }^{3} \mathrm{H}$-DFAA (mean specific activity $1.97 \mathrm{GBq}$ mat C, TRK440, Amersham, Buckinghamshire, UK) by heterotrophic bacterioplankton. ${ }^{3} \mathrm{H}$-DFAA was added to triplicate $10 \mathrm{ml}$ subsamples and a formalin-killed control at a final concentration of $0.1 \mathrm{nmoll}^{-1}$ of DFAA. Incubations were further processed as for BP. Turnover rate constants of DFAA were calculated as the ratio of the radioactivity incorporated over the radioactivity added.

\section{Collection and extraction of DNA}

DNA of the bacterial community was collected by filtering $0.5-1.0 \mathrm{l}$ of seawater onto a $0.2 \mu \mathrm{m}$ Nuclepore membrane ( $47 \mathrm{~mm}$ diameter). At coastal stations with high concentrations of SPM or Chl $a$, samples were prefiltered through a $5.0 \mu \mathrm{m}$ membrane. Filters of particle-associated $(>5 \mu \mathrm{m})$ and 


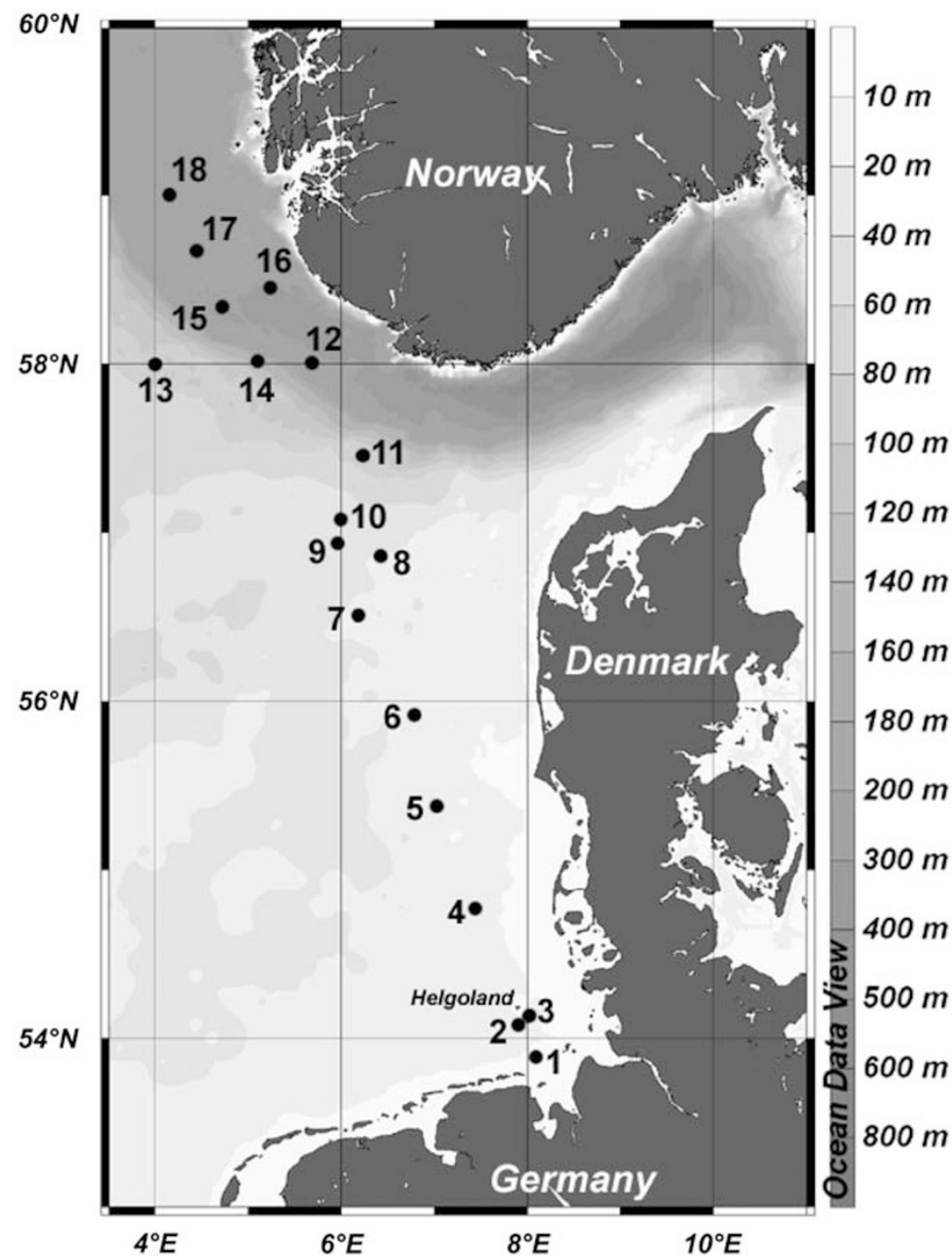

Figure 1 Bathymetry and sampling locations in the North Sea during cruises HE-238 (September 2005) and HE-249 (May 2006) with RV Heincke. For exact locations of the stations and dates of sampling, see Supplementary Table S1.

free-living bacteria $(0.2-5.0 \mu \mathrm{m})$, were transferred into sterile Eppendorf tubes and stored at $-80^{\circ} \mathrm{C}$. DNA was extracted as described by Giebel et al. (2009). Stocks of the extracted DNA were stored at $-80{ }^{\circ} \mathrm{C}$ and subsamples at $-20^{\circ} \mathrm{C}$ until further analysis.

PCR amplification of 16S rRNA gene fragments of the RCA cluster

To analyze the phylogenetic diversity of the RCA cluster, an RCA-specific Taqman probe RCATQ830R (Giebel et al., 2009) and additionally an RCAspecific primer RCA995R (Selje et al., 2004) were used as reverse primers in a PCR combined with the bacteria-specific primer 16S-27F (Lane, 1991). Both RCA-specific primers are $100 \%$ complementary to all available RCA 16S rRNA gene sequences deposited in GenBank and RPD (Ribosomal Database
Project) and have sufficient nucleotide coverage at the specific binding sites. Primer/probe design, PCR amplification, purification and sequencing of the amplicons were performed as described previously (Selje et al., 2004; Giebel et al., 2009). Phylogenetic analysis of the obtained clone sequences of RCA members was carried out using the GenBank database (http://www.ncbi.nlm.nih. gov) and the BioEdit Software (http://www.mbio. ncsu.edu/BioEdit/bioedit.html; Hall, 1999) for alignment comparison with representative sequences.

qPCR assays for bacterial, RCA and SAR11 $16 S$ rRNA genes

Assays were performed as described in detail by Giebel et al. (2009). Briefly, PCR reactions were performed in triplicates in a total volume of $25 \mu \mathrm{l}$ in optical grade tubes using the RealMasterMix Probe 
(5 PRIME, VWR International, Darmstadt, Germany). 16S rRNA genes of bacteria were detected according to Nadkarni et al. (2002) with a quantitative PCR (qPCR) efficiency ( $\mathrm{qPCR}_{\text {eff }}$ ) of $0.89 \pm 0.5$ and of the SAR11 clade according to Suzuki et al. (2001) with $\mathrm{qPCR}_{\text {eff }}=0.91 \pm 0.5$. The RCA-specific primer probe set has a $\mathrm{qPCR}_{\text {eff }}=0.92 \pm 0.5$. The abundances of RCA and SAR11 lineages were determined as the percentage of total bacterial 16S rRNA genes (ratio of group specific over total bacterial 16S rRNA genes). Only results with s.d. of $<10 \%$ within triplicate determinations are presented. The detection limit of the RCA-specific qPCR was determined as $0.073 \pm 0.003 \mathrm{fg}$ DNA (corresponding to $39.2 \pm 1.5$ copy numbers).

\section{Source and isolation of the RCA strain}

Seawater medium (SM) was prepared from autoclaved seawater, amended with thiosulfate (final concentration $10 \mathrm{~mm}$ ), a trace element solution and vitamins (Schut et al., 1993). A volume of $9 \mathrm{ml}$ of this medium was inoculated with $1 \mathrm{ml}$ surface seawater of the Wadden Sea, southern North Sea, collected on 13 May 2005 at high tide near Neuharlingersiel, Germany $\left(53^{\circ} 42^{\prime} \mathrm{N}, 0^{\circ} 43^{\prime} \mathrm{E}\right)$. The sample was subsequently serially diluted with SM 1:10, and dilution steps of $10^{-3}-10^{-9}$ were incubated at $15^{\circ} \mathrm{C}$ in the dark for 7 weeks. Dilution cultures were then screened by denaturing gradient gel electrophoresis of PCR-amplified 16S rRNA gene fragments for the presence of bacteria (Teske et al., 2000) and by an RCA-specific PCR assay and sequencing of the 16S rRNA gene for the presence of strains of the RCA cluster (Selje et al., 2004). All RCA-positive dilution steps were transferred to the SM and further incubated under the same conditions. After 60 days, denaturing gradient gel electrophoresis and RCA-specific PCR analyses showed that in five cultures, only one organism affiliated with the RCA cluster was present. Aliquots of these cultures were transferred again to the SM with and without thiosulfate and 10\% Marine Broth (MB 2216, Difco, Becton Dickinson, Lawrence, KS, USA). Subsequently, growth of the strains with different MB concentrations (10-80\% in $10 \%$ increments) at $15{ }^{\circ} \mathrm{C}$ in the dark was examined by monitoring the optical density at $600 \mathrm{~nm}\left(\mathrm{OD}_{600}\right)$ spectrophotometrically. Only cultures with $40 \% \mathrm{MB}$ of strain RCA23, obtained from a $10^{-7}$ dilution culture, grew reliably and hence were used for further investigations. For long-term storage, $0.5 \mathrm{ml}$ culture volumes of strain RCA23 were mixed with $0.75 \mathrm{ml}$ of sterile $88 \%$ glycerol and maintained at $-80^{\circ} \mathrm{C}$. These cultures served as inocula for further physiological experiments. Purity of the isolate was checked after each transfer by light and epifluorescence microscopy after staining with SybrGreen I (Lunau et al., 2005), by bacteria-specific denaturing gradient gel electrophoresis (Teske et al., 2000), sequencing of PCR amplified 16S rRNA genes
(Brinkhoff and Muyzer, 1997) and colony formation after spotting droplets of cell suspension onto agar plates.

\section{Growth tests}

Tests were conducted in $22.5 \mathrm{ml}$ metal-capped test tubes containing $5 \mathrm{ml}$ of either of the following media: (1) autoclaved seawater supplemented with $2 \mathrm{gl}^{-1}$ peptone (Difco), $0.4 \mathrm{gl}^{-1}$ yeast extract (Difco), equivalent to $40 \% \mathrm{MB}$ medium and denoted in the following as $40 \% \mathrm{MB} \mathrm{SB}$, trace element solution and vitamins (Schut et al., 1993); (2) artificial seawater (with identical sea salt composition as MB 2216) amended with the same supplements as for $40 \% \mathrm{MB}$ $\mathrm{SM}$, denoted in the following as $40 \% \mathrm{MB}$ artificial seawater medium. Growth in various defined minimal media with single substrates is described in the Supplementary Data section (S-Media). All tests were conducted in triplicates and with negative controls. Growth was determined by an increase in $\mathrm{OD}_{600}$ or by epifluorescence microscopy.

The temperature range for growth was examined between 4 and $35^{\circ} \mathrm{C}$ at intervals of $5{ }^{\circ} \mathrm{C}$ in the dark in $40 \% \mathrm{MB}$ SM. The $\mathrm{pH}$ range (4-10) for growth was tested at $15^{\circ} \mathrm{C}$ in the dark in increments of ca. 0.5, in $40 \% \mathrm{MB} \mathrm{SM}$ adjusted with sterile $\mathrm{HCl}$ and $\mathrm{NaOH}$ $(1 \mathrm{M}$ each). For determining the osmotolerance of the isolate, growth was examined at concentrations of 0 , $3,6,15,20,30,35,40,50,55,60 \mathrm{~g} \mathrm{NaCl} \mathrm{l}^{-1}$, using the MB medium diluted with deionized water or amended with concentrated $\mathrm{NaCl}$ solution $(3 \mathrm{M})$, respectively.

\section{Amplification of pufM gene fragments}

To amplify fragments of the pufM gene coding for the subunits of the reaction center of bacteriochlorophyll $a$ (a wide-spread characteristic of Roseobacters, Yutin et al., 2005), the primer set published by these authors was used (pufM_uniF and pufM uniR). PCR amplification was performed using an Eppendorf Mastercycler (Eppendorf Inc., Hamburg, Germany) or a Primus 25 cycler (MWG Biotech, Ebersberg, Germany) and 1-Units of RedTaq polymerase (Sigma, Deisenhofen, Germany) were used.

Sequencing and phylogenetic analysis

Sequences were analyzed by the ARB software package (ARB) (http://www.arb-home.de; Ludwig et al., 2004), by BLAST search (http://www.ncbi.nlm. nih.gov/blast) and by online analysis tools of the RDP (http://rdp.cme.msu.edu/; Cole et al., 2009). Sequences were aligned with representative sequences available in GenBank using the BioEdit Software (Hall, 1999). Chimera analysis was performed using the chimera-check program (Maidak et al., 2001).

Phylogenetic trees were constructed using the ARB software package (Ludwig et al., 2004) using neighbor-joining and maximum-likelihood analyses. Only almost full-length 16S rRNA gene sequences ( $>1300 \mathrm{bp}$ ) of all type strains of the Roseobacter 
group were considered in calculations for backbone trees. Shorter sequences were added afterwards by maximum parsimony.

The sequences obtained in this study are available from GenBank under accession no. GQ369962GQ369999.

\section{Results}

Hydrography

The study covered the eastern coastal regions of the North Sea (Figure 1, Supplementary Table S1). The potential sea-surface temperature decreased from the German Bight to the Norwegian trench, but temperatures were higher in Sep05 than in May06 (Figures 2a and b). Salinities ranged between 27.87 and 34.53 with reduced values in the German Bight and at stations further north where Skagerrak waters with lower salinity were present (Otto et al., 1990; Figures 2a and b). The vertical profiles show that the water column was stratified in both seasons with a warmer and less saline-mixed layer relative to the underlying water (Supplementary Figures S2, S3 and S4).
Biogeochemical and microbial properties

In Sep05, there was a pronounced diatom bloom in the German Bight, as shown by the highest concentrations of Chl $a$ and phaeopigments in the surface layer $(0-10 \mathrm{~m})$ in this area and much lower values further north (Figure 2c). Near-surface concentrations of SPM and particulate organic matter exhibited similar patterns of a pronounced south-north gradient and were closely correlated (Spearman's correlation $r=0.88, P<0.01$; data not shown). Data on concentrations of DOC and DFAA, bacterioplankton abundance, production and DFAA turnover rate constants varied substantially from the German Bight to the Norwegian trench and are shown in Supplementary Figure S1.

In May06, phytoplankton blooms dominated by diatoms were detected in the southern North Sea with highest concentrations of Chl $a$ and phaeopigments in surface waters at stations 5 and 6 and in the northern part at stations 14 and 17 (Figure 2d). Particularly low Chl a concentrations occurred in the central region at stations 7-10. Patterns of SPM and POC concentrations basically reflected those of Chl $a$ and phaeopigments and were closely correlated (Spearman's correlations Chl $a$-POC:
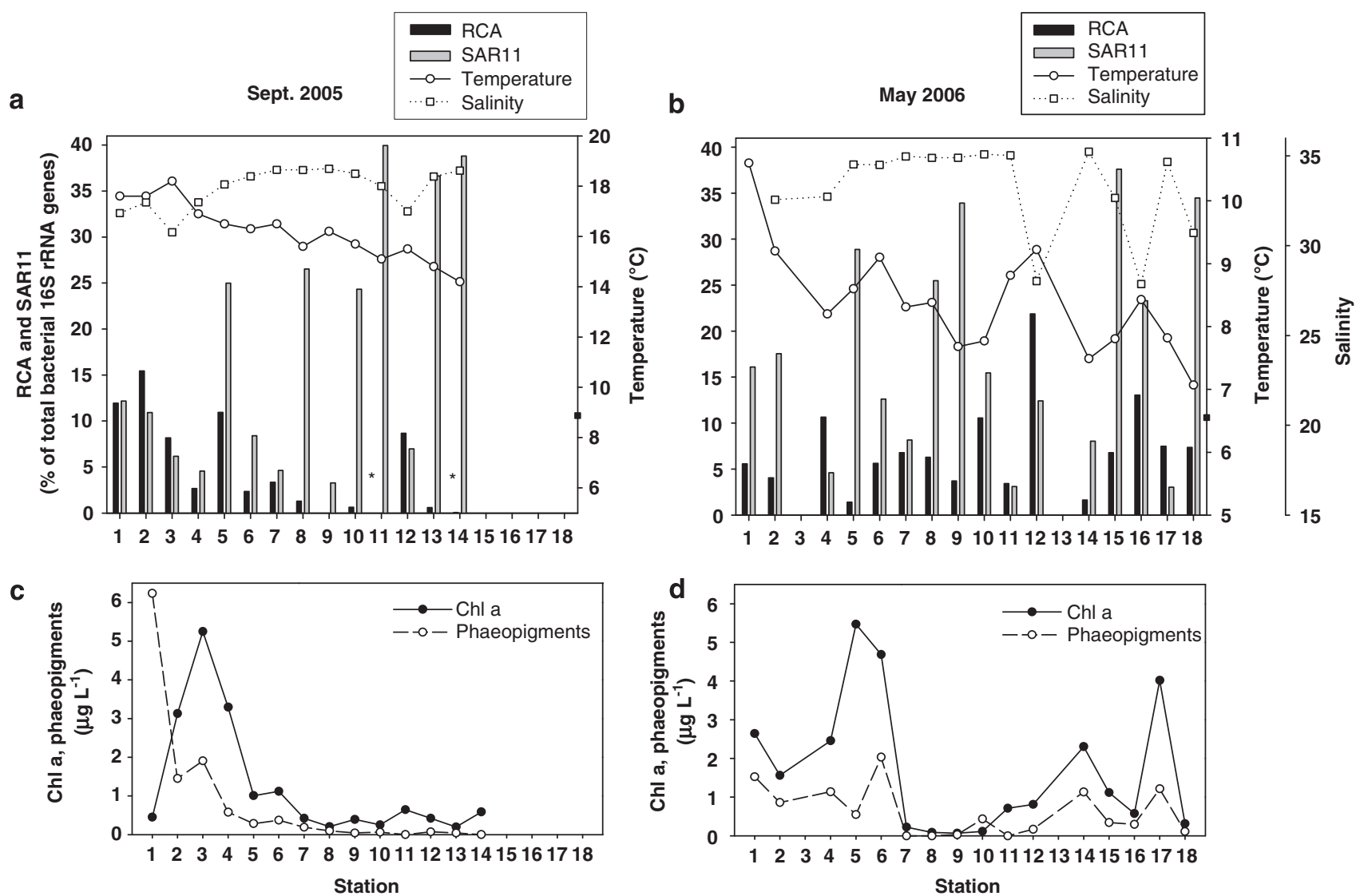

Figure 2 Abundance of the RCA cluster and SAR11 clade and various hydrographic and biological parameters assessed in the North Sea surface waters during cruises HE-238 in September 2005 and HE-249 in May 2006. (a, b) Abundances of the RCA cluster and SAR11 clade, salinity and temperature (the different scales must be noted); (c, d) Concentrations of chlorophyll $a$ (Chl $a$ ) and phaeopigments; *RCA phylotypes detected but abundance below the resolution of the $y$ axis. For exact locations of the stations and dates of sampling, see Supplementary Table S1. 
$r=0.94 ; \quad$ SPM-POC: $\quad r=0.91 ; \quad$ POC-phaeopigments: $r=0.78$, all $P<0.001)$. Data for bacterioplankton abundance are not available for May06. Concentrations of DFAA, rates of BP and DFAA turnover varied substantially over the transect and are shown in Supplementary Figure S1.

\section{RCA and SAR11 abundances}

RCA and SAR11 phylotypes were only detected in the $0.2-5.0 \mu \mathrm{m}$ fraction, that is, in the free-living bacterioplankton. In Sep05, RCA phylotypes were detected in surface waters of all stations, except station 9. In surface waters, the RCA cluster comprised $<2-15.4 \%$ of total bacterial $16 \mathrm{~S}$ rRNA genes (Figure 2a). There was a general trend of decreasing proportions from south to north with the exceptions of stations 5 and 12 . The mean for all stations was $4.4 \% \pm 5.5 \%$. The SAR11 clade constituted between 2.5 and $39.9 \%$ of total bacterial $16 \mathrm{~S}$ rRNA genes. In contrast to the RCA cluster, highest proportions in surface waters occurred toward the northern part of the transect and at stations 5, 8 and 10 (Figure 2a). Particularly low proportions of the SAR 11 clade were detected in the German Bight (stations 1-4) and at stations 7, 9 and 12. Only at stations $1,2,3$ and 12 were proportions of the SAR11 clade equal to or lower than those of the RCA cluster. The overall mean of the SAR11 clade was $19.7 \% \pm 17.4 \%$. Together, both phylogenetic lineages constituted between 3.3 and $60.3 \%$ of total bacterial 16S rRNA genes.

In May06, RCA phylotypes comprised between 1.4 and $21.9 \%$ of total $16 \mathrm{~S}$ rRNA genes in surface waters with the highest proportion at station 12 (Figure 2b). It is noteworthy that station 12 showed a considerably reduced salinity and high RCA abundances in both seasons. At most stations, proportions of RCA phylotypes ranged between 4 and $11 \%$ and the mean for all stations was $7.5 \% \pm 5.0 \%$. There was no consistent pattern of the occurrence of RCA phylotypes with the phytoplankton bloom. The SAR11 clade constituted $3.0-37.0 \%$ of total bacterial $16 \mathrm{~S}$ rRNA genes (Figure $2 \mathrm{~b}$, mean $=17.8 \% \pm 11.6 \%$ ). Values exceeding $25 \%$ occurred at station 5 and further north. At stations 4, 12 and 17, proportions of the RCA cluster exceeded those of the SAR11 clade. Together, both phylogenetic lineages constituted between 6.5 and $44.4 \%$ of total bacterial $16 \mathrm{~S}$ rRNA genes.

Supplementary Figures S2, S3 and S4 show selected profiles of Sep05 and May06 from the southern, central and northern regions of the abundance of the RCA cluster and the SAR11 clade together with concentrations of Chl $a$, phaeopigments, bacterioplankton abundance, rates of $\mathrm{BP}$ and DFAA turnover. In quite a few profiles, RCA abundance decreased with increasing depth and covaried with temperature. Often, Chl $a$, bacterial numbers and rates of BP and DFAA turnover were high in the surface layer together with enhanced percentages of RCA and/or SAR11.

\section{Correlation analysis}

To elucidate possible controlling factors of the occurrence and growth of the RCA cluster and the SAR11 clade in the North Sea, a correlation analysis of the abundance of these phylogenetic lineages with environmental and plankton-derived parameters was conducted. We performed a Spearman's rank correlation analysis (SigmaStat Software, Version 3.5, San Jose, CA, USA), including an $\alpha$-correction after Hommel (1988), for the entire data set and for subsets of the southern (stations 1-6), central (stations 7-11) and northern regions (stations 12-18) and for data of all depths, as well as for surface waters $(0-10 \mathrm{~m})$.

In Sep05, RCA abundance in surface waters was positively correlated with phaeopigment concentration and temperature (Table 1). Considering the entire data set, RCA abundance was not only

Table 1 Significant Spearman's correlations of the abundance of the RCA cluster and SAR11 clade (\% of total bacterial 16S rRNA genes) with various parameters determined in September 2005 and May 2006 in the North Sea

\begin{tabular}{|c|c|c|c|c|}
\hline Parameter $A$ & Parameter B & $r_{S}$ & $\mathrm{P}$-value & $\mathrm{N}$ \\
\hline \multicolumn{5}{|l|}{ September 2005} \\
\hline Stations 1-14 & Surface & & & \\
\hline RCA \%bacteria & Temperature & 0.72 & ** & 14 \\
\hline RCA \%bacteria & Phaeopigments & 0.81 & $* *$ & 13 \\
\hline Stations 1-14 & All depths & & & \\
\hline RCA \%bacteria & Temperature & 0.46 & $* *$ & 45 \\
\hline RCA \%bacteria & Salinity & -0.49 & ** & 45 \\
\hline RCA \%bacteria & Chl $a$ & 0.38 & * & 39 \\
\hline RCA \%bacteria & Phaeopigments & 0.37 & * & 39 \\
\hline RCA \%bacteria & SPM & 0.62 & ** & 38 \\
\hline RCA \%bacteria & POM & 0.48 & ** & 38 \\
\hline RCA \%bacteria & DOC & 0.52 & ** & 25 \\
\hline RCA \%bacteria & $\mathrm{BP}$ & 0.48 & ** & 37 \\
\hline RCA \%bacteria & DFAA turnover rate & 0.50 & * & 24 \\
\hline Stations 1-6 & All depths & & & \\
\hline RCA \%bacteria & Salinity & -0.65 & $* *$ & 16 \\
\hline RCA \%bacteria & DOC & 0.78 & ** & 11 \\
\hline RCA \%bacteria & DFAA turnover rate & 0.87 & ** & 10 \\
\hline RCA \%bacteria & SAR11\%Bacteria & 0.69 & ** & 16 \\
\hline SAR11 \%bacteria & DFAA turnover rate & 0.69 & * & 10 \\
\hline \multicolumn{5}{|l|}{ May 2006} \\
\hline Stations 7-11 & All depths & & & \\
\hline SAR11 \%bacteria & POC & -0.77 & ** & 11 \\
\hline Stations $12-18$ & All depths & & & \\
\hline RCA \%bacteria & Salinity & -0.52 & ** & 28 \\
\hline
\end{tabular}

Abbreviations: BP, bacterial production; DFAA, dissolved free amino acid; DOC, dissolved organic carbon; POC, particulate organic carbon; POM, particulate organic matter; SPM, suspended particulate matter; RCA, Roseobacter clade affiliated;

Given are $r$, significance levels $\left({ }^{*} P<0.05\right.$ : ${ }^{*} P<0.01$ :) including an $\alpha$-correction after Hommel (1988) and the number of data point $(N)$ for the entire data sets and for subsets of data of various regions of near surface values $(0-15 \mathrm{~m})$ and from the entire water column. Only data with $N>10$ are presented using the Spearman Rank Correlation tool of the SigmaStat Software (Version 3.5, Systat Software). 


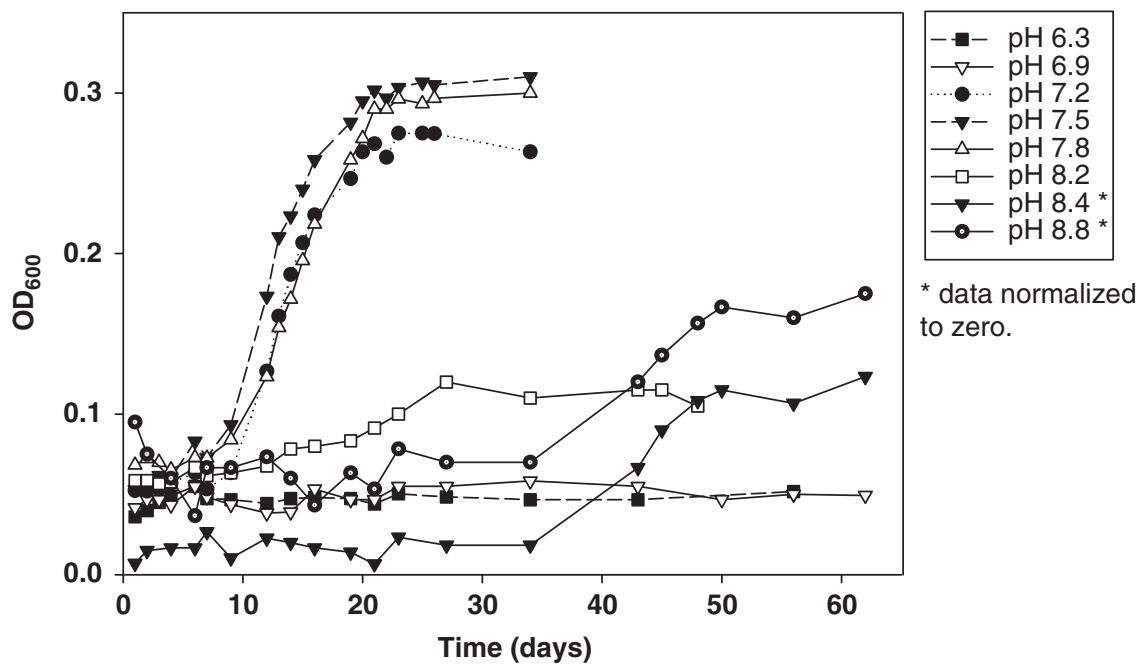

Figure 3 Growth of strain RCA23 at pH values between 6.3 and 8.8, measured as change in optical density at $600 \mathrm{~nm}\left(\mathrm{OD}_{600}\right)$. The mean of triplicate cultures is shown.

positively correlated with these parameters but also with quite a few other parameters assessed, such as SPM, DOC, DFAA turnover rates and BP, respectively. Some correlations also existed when considering only the southern region with stations 1-6. In May06, RCA abundance was only inversely correlated with salinity for the data set of the northern stations, whereas in Sep05, this correlation existed for the entire data set and the southern stations.

The SAR11 abundance in Sep05 correlated positively only with the DFAA turnover rate constant and RCA abundance for the data subset of stations 1-6, and in May06 correlated negatively with POC for the data subset of stations 7-11 (Table 1).

\section{Isolation and characteristics of strain RCA23}

We isolated a strain of the RCA cluster from a $10^{-7}$ dilution culture, that is, strain RCA23. This isolate grew only in media containing yeast extract and peptone like MB and much more reliably in SM as compared with the artificial seawater medium. At MB concentrations, $>40 \%$ growth was inhibited. No growth in the defined minimal media with single substrates was observed (see Supplementary Data section, S-Media). Inoculation of liquid cultures onto $40 \% \mathrm{MB} \mathrm{SM}$ on agar plates incubated for 14 days at $20^{\circ} \mathrm{C}$ in the dark yielded transparent to light-beige colonies $<1 \mathrm{~mm}$ in size, smooth and convex and with regular edges. Subsequent transfer to fresh agar plates resulted in much weaker and unreliable growth.

Strain RCA23 grew in liquid culture at $\mathrm{NaCl}$ concentrations from 1.5 to $5.0 \%(\mathrm{w} / \mathrm{v})$ with an optimum between 3.0 and $3.5 \%$. Temperature tolerance ranged from 10 to $30^{\circ} \mathrm{C}$ and optimum growth occurred at $25^{\circ} \mathrm{C}$. No growth was observed at 4 and $35^{\circ} \mathrm{C}$. Sustainable growth occurred in a narrow $\mathrm{pH}$ range of $7.0-8.1$; $\mathrm{pH}$ optimum was
7.5 and growth at $\mathrm{pH} 7.8$ was almost similar, whereas growth at 8.2 was already very weak (Figure 3). Below pH 7, no growth occurred, and for $\mathrm{pH} 8.4$ and 8.8, growth was observed only after 40 days of incubation. The pufM gene was detected in strain RCA23 and a BLAST analysis showed $100 \%$ sequence identity with clones belonging exclusively to the Roseobacter group (for example, clone EBAC00-60D04, AE008921, Beja et al. (2002) or clone C40, AY731168, Jiao et al. (2007).

\section{Phylogeny of strain RCA23 and RCA $16 S$ rRNA gene amplicons}

Most closely related and validly classified species to strain RCA23 (GQ369962) are Octadecabacter antarcticus strain 307 (U14583, 95.2\%) and Octadecabacter arcticus strain 238 (U73725, 94.4\%). RCA23 forms a distinct monophyletic lineage with other RCA isolates. Isolates IMCC1909 and IMCC1923 have a $100 \%$ sequence identity of their almost complete 16S rRNA genes to RCA23 and IMCC1933 has one nucleotide difference. RCA strains do not affiliate with any described genus (Figure 4). Genotypic and phenotypic differences of our isolate from previously described genera support its proposal as 'Candidatus Planktomarina temperata' gen. nov., sp. nov. with RCA23 as the type strain.

Sequence analysis of the obtained RCA-specific PCR amplicons (561-884 bp) revealed 3 distinct $16 \mathrm{~S}$ rRNA gene sequence signatures. One ribotype was $100 \%$ identical with the $16 \mathrm{~S}$ rRNA gene alignment characteristics of strain RCA23 (signature RCA-NSI), a second had one nucleotide difference to strain RCA23 and the identical 16S rRNA gene alignment characteristics of strain IMCC1933 (signature RCANSII, amplicon lengths: 561-781 bp, mean $692 \mathrm{bp}$ ) and a third ribotype differed in 3 of 837 nucleotides compared with the alignment of strain RCA23 (signature RCA-NSIII). This sequence variability of 


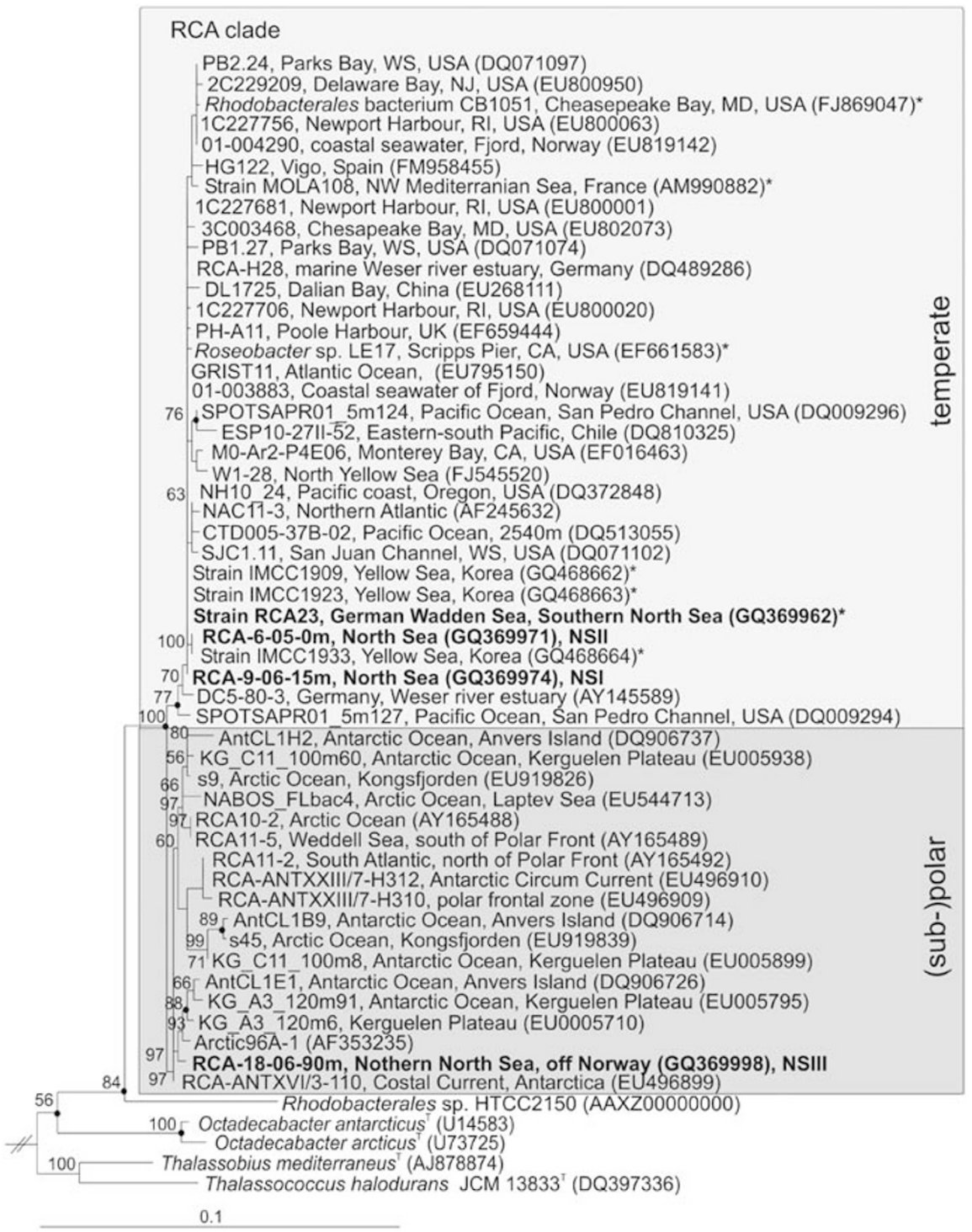

Figure 4 Neighbor-joining tree showing the phylogeny of the three RCA ribotypes (NSI, NSII, NSIII, bold type) of the North Sea transects and strain RCA23 (bold type) within the RCA cluster based on 16S rRNA gene sequence similarity. NSI, NSII and NSIII were represented by longest sequences of each ribotype and added later to the final tree using the maximum parsimony option of the ARB program. The backbone tree considered only sequences $>1300 \mathrm{bp}$ and from different locations. Several sequences from the same location were only included if they show sequence variations. Filled circles indicate nodes also recovered reproducibly with maximum-likelihood calculation. Numbers at the nodes are bootstrap values (only $>50 \%$ are shown) from 1500 replicates. Methylococcus capsulatus ACM1292 (X72770) and Thiotrix nivea JP2 (L40993) were used as outgroup (not shown) to define the root of the tree. GenBank accession numbers are given in parentheses. Bar, 0.1 substitutions per nucleotide position. *, isolated strains.

the $16 \mathrm{~S}$ rRNA gene always appeared at the same nucleotide positions (that is, at 189, 381, 420 after Escherichia coli alignment). The ribotype RCA-NSI was detected in 28 of 34 randomly chosen samples from various stations and depths of both transects (Supplementary Table S1), whereas the ribotype RCA-NSII was detected only in 7 samples from 4 stations. In Sep05, it occurred at station 6 at the surface and at station 12 at $30 \mathrm{~m}$, and in May06 at stations 12,14 and 18 at a few depths, only at station 12 together with RCA-NSI. The ribotype RCA-NSIII was detected in May06 at station 18 at $90 \mathrm{~m}$ depth as the only representative of the RCA cluster (Supplementary Table S2).

\section{Discussion}

This study shows that a population of the RCA cluster is an abundant component of the bacterioplankton in the North Sea, responding to hydrographic and plankton dynamics in the spring and fall. In the majority of samples, only one distinct RCA ribotype, identical with the 16S rRNA gene sequence of strain RCA23, was present. Only at station 12, this ribotype occurred with another RCA ribotype. Together, all three ribotypes detected constituted up to 15 and $21 \%$ of total bacterial $16 \mathrm{~S}$ rRNA genes in Sep05 and May06, respectively. To our knowledge, this is the first report of one 
population of such closely related ribotypes ( $\geqslant 99.6 \%$ of the $16 \mathrm{~S}$ rRNA gene), which constitutes such a high proportion of the (photo)heterotrophic marine bacterioplankton. The results further support and extend previous findings that the RCA cluster is an abundant and dynamic component of the marine bacterioplankton in temperate to polar seas (Selje et al., 2004; Brown et al., 2005; Malmstrom et al., 2007; West et al., 2008; Giebel et al., 2009).

The growth tests shed some light on characteristic traits of strain RCA23. Most striking is its narrow $\mathrm{pH}$ range of growth (see below) and the presence of the pufM gene. In fact, preliminary data of wholegenome sequencing of this strain with a genome size of $3.2 \mathrm{Mb}$ showed the presence of the entire bacteriochlorophyll $a$ operon (S Voget et al., unpublished data), thus substantiating our finding and implying that strain RCA23 is able to carry out aerobic anoxygenic photosynthesis. If this holds true for the entire RCA cluster, this abundant group is a further potential component of the photoheterotrophic bacterioplankton in temperate to polar oceans. Comparative growth experiments of strain RCA23 under dark vs light:dark conditions, however, did not yield any difference. Furthermore, we were so far unable to examine the substrate spectrum of this mesophilic bacterium because we did not succeed in growing it on a defined minimal medium. Growth of RCA23 occurred preferentially in liquid medium and seemed to depend on certain complex, but unknown substrates present in the MB. This notion may reflect that growth of this strain depends on some essential compounds usually present in its habitat. The rather small genome as compared with most other Roseobacter species (Brinkhoff et al., 2008; also see http:// www.roseobase.org) may be an adaptation to the strictly pelagic life, as suggested for Pelagibacter ubique of the SAR11 clade (Giovannoni et al., 2005).

It was intriguing that strain RCA23 had a rather narrow $\mathrm{pH}$ range with an optimum at 7.5-7.8 and that growth at $\mathrm{pH} 8.2$ was already significantly lower. A rather similar pH-dependent growth pattern has also been reported for Leisingera methylohalidivorans of the Roseobacter group (Schaefer et al., 2002). The authors suggested that the drop of the growth curve at $\mathrm{pH} \sim 8$ may be due to precipitation of magnesium and calcium salts and not a true physiological response. We cannot rule out that this assumption is also true for strain RCA23. However, the $\mathrm{pH}$ optimum complies with the annual $\mathrm{pH}$ range in the Wadden Sea (Stevens et al., 2005) from where strain RCA23 was isolated, suggesting that it is well adapted to its habitat. The Wadden Sea also shows a salinity range of approximately 28-31, which is lower than the North Sea beyond the Wadden Sea (Stevens et al., 2005). This notion is consistent with the inverse correlation between RCA abundance and salinity we found (see below).
This is the second report of an isolate of the RCA cluster. For the other isolate (strain LE17), retrieved from a dinoflagellate bloom in the Southern California Bight of the Pacific, no growth or physiological traits are known, except that the host, Lingulodinium polyedrum, supports its growth and that the isolate can inhibit the host's growth (Mayali et al., 2008). Fandino et al. (2001) already found a sequence signature identical to isolate LE17 and strain RCA23 in the particle-associated bacterial fraction during a bloom of $L$. polyedrum at the same geographic location, indicating that RCA bacteria may dwell under certain conditions in close association with particles and micoalgae. Another closely related isolate is available, which has been subjected to whole-genome sequencing (strain HTCC 2150, http://www.roseobase.org). As its 16S rRNA gene has a sequence similarity of only $96 \%$ to strain RCA23 and its genome does not carry the operon encoding for bacteriochlorophyll $a$ synthesis, it does not affiliate to the RCA cluster, which has a within-cluster sequence similarity of the $16 \mathrm{~S}$ rRNA gene of $>98 \%$. This was confirmed by phylogenetic analyses based on almost complete 16S rRNA gene sequences (Figure 4). All these data support the proposal of RCA23 as the type strain of 'Cand. Planktomarina temperata' gen. nov., sp. nov.

Analyses by fluorescent in situ hybridization in the German Bight and the northern North Sea indicated that the Roseobacter group constituted up to 9 and $24 \%$ of total bacterioplankton numbers, respectively (Eilers et al., 2000; Zubkov et al., 2001). This group dominated the high nucleic acid, that is, the most active fraction, of the bacterioplankton during an E. huxleyi bloom in the northern North Sea (Zubkov et al., 2002) and also largely dominated the glucose uptake in the German Bight, as shown by microautoradiography coupled to fluorescent in situ hybridization (Alonso and Pernthaler, 2006). We only assessed the abundance of the RCA cluster and not that of the entire Roseobacter group because it is not possible to reliably target this entire group by a qPCR assay. Reanalysis of the specificity of the primer-probe system developed by Suzuki et al. (2001) on the basis of presently published 16S rRNA gene sequences showed that this system does not detect all Roseobacter genera but even a few nonRoseobacter phylotypes, thus making it unspecific. A search for a more specific primer probe by using RDP, GenBank and the ARB software package (Ludwig et al., 2004) was not successful because all candidates discriminate against a considerable number of Roseobacter phylotypes. The abundances of the RCA cluster we found are equivalent to major proportions or even close to those of the total Roseobacter group reported by other studies and detected by different approaches (see above). Hence, we assume that the RCA cluster represents a major, presumably often the dominant fraction of the Roseobacter group in the North Sea. The various significant correlations of the RCA cluster to 
biogeochemical parameters indicate that this cluster is a prominent and active component of the bacterioplankton in the North Sea. The positive correlation between RCA abundance and phaeopigments, a proxy for decaying phytoplankton, suggests that RCA bacteria use DOC released from senescent phytoplankton cells.

The abundance of the RCA cluster was inversely correlated with salinity. The salinity range covered by this study was from 27.87 to 34.53 . From a global survey, it is known that the RCA cluster does not occur in subtropical and tropical oceans, but only in temperate and polar oceans, and that it shows its highest abundances in the Southern Ocean (Selje et al., 2004; Giebel et al., 2009). The subtropical and tropical oceans show higher salinities, exceeding 35, than do the temperate and polar oceans, the latter with salinities below 33. Hence, the correlation we found is consistent with the global distribution patterns of the RCA cluster with respect to the salinity distribution and suggests that salinity may be a factor in shaping the global distribution patterns of this cluster.

The SAR11 clade was more abundant than the RCA cluster in the great majority of the stations. This is no surprise, considering that this clade comprises phylotypes with a sequence similarity of $>89.9 \%$ of the $16 \mathrm{~S}$ rRNA gene (Field et al., 1997), similar to that of the Roseobacter group $(88 \%$, Brinkhoff et al., 2008). Several studies have shown that the SAR11 clade consists of several subgroups with different preferences to environmental and biological variables (Morris et al., 2005; Carlson et al., 2009; Fuhrman, 2009). Therefore, it seems reasonable that much fewer correlations were found between the occurrence of SAR11 and environmental and biological variables in this study, as presumably several subgroups of this clade were lumped together in our qPCR analysis, targeting the entire SAR11 clade. Furthermore, there are indications that the SAR11 clade is less involved in substrate turnover in temperate seas and in the Southern Ocean than the Roseobacter group. In a study from the North Sea mentioned above, Alonso and Pernthaler (2006) found that the SAR11 clade exhibited a much lower fraction of cells taking up glucose as compared with its numerical fraction of the bacterioplankton. The active fraction of the SAR11 clade was also far below that of the Roseobacter group. Furthermore, West et al. (2008) found that in the Southern Ocean, the abundance of the SAR11 clade on the basis of the 16S rRNA gene was higher than that of the $16 \mathrm{~S}$ rRNA, that is, the active fraction. Hence, it is consistent with these notions to assume that in the North Sea, the SAR11 clade is less involved in substrate turnover than implied by its numerical abundance and that other phylogenetic lineages, including the Roseobacter group and its RCA cluster, are relatively more involved.

In conclusion, we have shown that a population of the RCA cluster, dominated by a ribotype with a $16 \mathrm{~S}$
rRNA gene sequence identical to strain RCA23 ('Cand. Planktomarina temperata'), is an abundant component of the bacterioplankton in the North Sea, constituting up to $21 \%$ of total bacterial $16 \mathrm{~S}$ rRNA genes and 4.5 and $7.5 \%$ of total $16 \mathrm{~S}$ rRNA genes as mean values in Sep05 and May06, respectively. Its population dynamics and correlations with plankton-related parameters indicate that it is actively involved in and important for processing planktonderived organic matter. Growth characteristics of strain RCA23 and the inverse correlation of the population of the RCA cluster with salinity appear to be adaptations to the less-saline waters of coastal seas of the temperate zone. It is remarkable that this population at several stations constitutes proportions similar to or exceeding those of the SAR11 clade, a much broader phylogenetic lineage. The correlation analysis suggests that the SAR11 clade is less involved in processing plankton-derived organic matter than the RCA cluster. The SAR11 clade comprises organisms with a much smaller genome than other bacterioplankton lineages, including the Roseobacter group and also strain RCA23 (see above; Giovannoni et al., 2005; Brinkhoff et al., 2008). A small genome appears to be an adaptation to an oligotrophic lifestyle (Lauro et al., 2009) and suggests that the SAR11 clade and the Roseobacter group exhibit contrasting lifestyles. The SAR11 clade seems to be particularly adapted to oligotrophic conditions typical for oceanic regions and central oceanic gyres, not responding readily to phytoplankton bloom dynamics. In contrast, the Roseobacter group and in particular its largest subgroup, the RCA cluster, appears well adapted to more nutrient-rich, that is, mesotrophic regions, mainly in the temperate to polar zones and responds more readily to phytoplankton bloom dynamics.

\section{Acknowledgements}

We thank the crew of the RV Heincke for their valuable support on shipboard, T Badewien and A Braun for the hydrographic data and technical assistance in sampling. We are grateful to B Kuerzel, A Schlingloff and R Weinert for their skilled technical support in sample analysis, O Dellwig for the DOC data and C Beardsley for help in the correlation analysis. Comments of three anonymous reviewers on an earlier version of this paper are gratefully acknowledged.

\section{References}

Alderkamp AC, Sintes E, Herndl GJ. (2006). Abundance and activity of major groups of prokaryotic plankton in the coastal North Sea during spring and summer. Aquat Microb Ecol 45: 237-246.

Alonso C, Pernthaler J. (2006). Roseobacter and SAR11 dominate microbial glucose uptake in coastal North Sea waters. Environ Microbiol 8: 2022-2030. 
Alonso-Gutiérrez J, Lekunberri I, Teira E, Gasol JM, Figueras A, Novoa B. (2009). Bacterioplankton composition of the coastal upwelling system of 'Ría deVigo', NWSpain. FEMS Microbiol Ecol 70: 493-505.

Alonso-Sáez L, Balagué V, Sà EL, Sánchez O, González JM, Pinhassi J et al. (2007). Seasonality in bacterial diversity in north-west Mediterranean coastal waters: assessment through clone libraries, fingerprinting and FISH. FEMS Microbiol Ecol 60: 98-112.

Beja O, Suzuki MT, Heidelberg JF, Nelson WC, Preston CM, Hamada T et al. (2002). Unsuspected diversity among marine aerobic anoxygenic phototrophs. Nature 415: 630-633.

Brinkhoff T, Giebel HA, Simon M. (2008). Diversity, ecology, and genomics of the Roseobacter clade: a short overview. Arch Microbiol 189: 531-539.

Brinkhoff T, Muyzer G. (1997). Increased species diversity and extended habitat range of sulfur-oxidizing Thiomicrospira spp. Appl Environ Microbiol 63: 3789-3796.

Brown M, Schwalbach M, Hewson I, Fuhrman J. (2005). Coupling 16S-ITS rDNA clone libraries and automated ribosomal intergenic spacer analysis to show marine microbial diversity: development and application to a time series. Environ Microbiol 7: 1466-1479.

Carlson CA, Morris R, Parsons R, Treusch AH, Giovannoni SJ, Vergin K. (2009). Seasonal dynamics of SAR11 populations in the euphotic and mesopelagic zones of the northwestern Sargasso Sea. ISME J 3: 283-295.

Cole JR, Wang Q, Cardenas E, Fish J, Chai B, Farris RJ et al. (2009). The ribosomal database project: improved alignments and new tools for rRNA analysis. Nucleic Acids Res 37: 141-145.

Dellwig O, Bosselmann K, Kölsch S, Hentscher M, Hinrichs J, Böttcher ME et al. (2007). Sources and fate of manganese in a tidal basin of the German Wadden Sea. J Sea Res 57: 1-18.

Eilers H, Pernthaler J, Glöckner FO, Amann R. (2000). Culturability and in situ abundance of pelagic bacteria from the North Sea. Appl Environ Microbiol 66: 3044-3051.

Eilers H, Pernthaler J, Peplies J, Glöckner FO, Gerdts G, Amann R. (2001). Isolation of novel pelagic bacteria from the German Bight and their seasonal contributions to surface picoplankton. Appl Environ Microbiol 67: $5134-5142$.

Eisma D. (1987). The North Sea: an overview. Phil Trans $R$ Soc Lond 316: 461-487.

Fandino LB, Riemann L, Steward GF, Long RA, Azam F. (2001). Variations in bacterial community structure during a dinoflagellate bloom analyzed by DGGE and 16S rDNA sequencing. Aquat Microb Ecol 23: 119-130.

Field KG, Gordon D, Wright T, Rappe M, Urbach E, Vergin K et al. (1997). Diversity and depth-specific distribution of SAR11 cluster rRNA genes from marine planktonic bacteria. Appl Environ Microbiol 63: 63-70.

Fuchs BM, Spring S, Teeling H, Quast C, Wulf J, Schattenhofer M et al. (2007). Characterization of a marine gammaproteobacterium capable of aerobic anoxygenic photosynthesis. Proc Natl Acad Sci USA 108: 2891-2896.

Fuhrman JA. (2009). Microbial community structure and its functional implications. Nature 459: 193-199.

Fuhrman JA, Hewson I, Schwalbach MS, Steele JA, Brown MV, Naeem S. (2006). Annually reoccurring bacterial communities are predictable from ocean conditions. Proc Natl Acad Sci USA 103: 13104-13109.

Gerdts G, Wichels A, Döpke H, Klings K-W, Gunkel W, Schütt C. (2004). A long-term study of microbial parameters near Helgoland (German Bight, North Sea): historical view and future perspectives. Helgoland Mar Res 58: 230-242.

Giebel HA, Brinkhoff T, Zwisler W, Selje N, Simon M. (2009). Distribution of Roseobacter RCA and SAR11 lineages and distinct bacterial communities from the subtropics to the Southern Ocean. Environ Microbiol 11: 2164-2178.

Giovannoni SJ, Stingl U. (2005). Molecular diversity and ecology of microbial plankton. Nature 437: 343-348.

Giovannoni SJ, Stingl U. (2007). The importance of culturing bacterioplankton in the 'omics' age. Nature Rev Microbiol 5: 820-826.

Giovannoni SJ, Tripp HJ, Givan S, Podar M, Vergin KL, Baptista D et al. (2005). Genome streamlining in a cosmopolitan oceanic bacterium. Science 309: 1242-1245.

Hall TA. (1999). BioEdit: a user-friendly biological sequence alignment editor and analysis program for Windows 95/98/NT. Nucl Acids Symp Ser 41: 95-98.

Hommel G. (1988). A stage-wise rejective multiple test procedure based on a modified Bonferroni test. Biometrika 75: 383-386.

Jiao N, Zhang Y, Zeng Y, Hong N, Liu R, Chen F et al. (2007). Distinct distribution pattern of abundance and diversity of aerobic anoxygenic phototrophic bacteria in the global ocean. Environ Microbiol 9: 3091-3099.

Lauro FM, McDougald D, Thomas T, Williams TJ, Egan S, Rice $S$ et al. (2009). The genomic basis of trophic strategy in marine bacteria. Proc Natl Acad Sci USA 106: 15527-15533.

Lane DJ. (1991). 16S/23S rRNA sequencing. In Stackebrandt E, Goodfellow M. (Eds.). Nucleic Acid Technology in Bacterial Sysematics. John Wiley and Sons: New York, USA pp. 115-175.

Ludwig W, Strunk O, Westram R, Richter L, Meier H, Yadhukumar et al. (2004). ARB: a software environment for sequence data. Nucl Acids Res 32: 1363-1371.

Lunau M, Lemke A, Walther K, Martens-Habbena W, Simon M. (2005). An improved method for counting bacteria in samples with high proportions of particleassociated cells by epifluorescence microscopy. Environ Microbiol 7: 961-968.

Lunau M., Lemke A, Dellwig O, Simon M. (2006). Physical and biogeochemical controls of microaggregate dynamics in a tidally affected coastal ecosystem. Limnol Oceanogr 51: 847-859.

Maidak BL, Cole JR, Lilburn TG, Parker CT, Saxman PR, Farris RJ et al. (2001). The RDP-II (Ribosomal Database Project). Nucl Acids Res 29: 173-174.

Malmstrom RR, Straza TRA, Cottrell MT, Kirchman DL. (2007). Diversity, abundance, and biomass production of bacterial groups in the western Arctic Ocean. Aquat Microb Ecol 47: 45-55.

Mayali X, Franks PJS, Azam F. (2008). Cultivation and ecosystem role of a marine Roseobacter clade-affiliated cluster bacterium. Appl Environ Microbiol 74: 2595-2603.

Morris RM, Rappé MS, Connon SA, Vergin KL, Siebold WA, Carlson CA et al. (2002). SAR11 clade dominates ocean surface bacterioplankton communities. Nature 420: 806-810. 
Morris RM, Vergin KL, Cho JC, Rappe MS, Carlson CA, Giovannoni SJ. (2005). Temporal and spatial response of bacterioplankton lineages to annual convective overturn at the bermuda atlantic time-series study site. Limnol Oceanogr 50: 1687-1696.

Nadkarni MA, Martin FE, Jacques NA, Hunter N. (2002). Determination of bacterial load by real-time PCR using a broad-range (universal) probe and primers set. Microbiology 148: 257-266.

Nusch EA. (1999). Chlorophyllbestimmung. In: von Tuempling W, Friedrich G. (eds). Biologische Gewässeruntersuchung. G Fischer, Stuttgart: Germany, pp 368-375.

Otto L, Zimmermann JTF, Furnes GK, Mork M, Saetre R, Becker G. (1990). Review of the physical oceanography of the North Sea. Neth J Sea Res 26: 161-238.

Rappé MS, Connon SA, Vergin KL, Giovannoni SJ. (2002). Cultivation of the ubiquitous SAR11 marine bacterioplankton clade. Nature 418: 630-633.

Reinthaler T, Winter C, Herndl GJ. (2005). Relationship between bacterioplankton richness, respiration, and production in the southern North Sea. Appl Environ Microbiol 71: 2260-2266.

Rink B, Seeberger S, Martens T, Duerselen C, Simon M, Brinkhoff T. (2007). Effects of a phytoplankton bloom in a coastal ecosystem on the composition of bacterial communities. Aquat Microb Ecol 48: 47-60.

Sapp M, Wichels A, Gerdts G. (2007). Impacts of cultivation of marine diatoms on the associated bacterial community. Appl Environ Microbiol 73: 3117-3120.

Schaefer JK, Goodwin KD, McDonald IR, Murrell JC, Oremland RS. (2002). Leisingera methylohatidivorans. gen nov., sp nov., a marine methylotroph that grows on methyl bromide. Int J Syst Evol Microbiol 52: 851-859.

Schut F, Devries EJ, Gottschal JC, Robertson BR, Harder W, Prins RA et al. (1993). Isolation of typical marinebacteria by dilution culture-growth, maintenance, and characteristics of isolates under laboratory conditions. Appl Environ Microbiol 59: 2150-2160.

Selje N, Simon M, Brinkhoff T. (2004). A newly discovered Roseobacter cluster in temperate and polar oceans. Nature 427: 445-448.

Simon M, Azam F. (1989). Protein content and protein synthesis rates of planktonic marine bacteria. Mar Ecol Prog Ser 51: 201-213.
Sowell SM, Norbeck AD, Lipton MS, Nicora CD, Callister SJ, Smith RD et al. (2008). Proteomic analysis of stationary phase in the marine bacterium 'Candidatus Pelagibacter ubique’. Appl Environ Microbiol 74: 4091-4100.

Stevens H, Brinkhoff T, Simon M. (2005). Composition and seasonal dynamics of free-living, aggregate- and sediment surface-associated bacterial communities in the German Wadden Sea. Aquat Microb Ecol 38: 15-30.

Suzuki MT, Preston CM, Chavez FP, DeLong EF. (2001). Quantitative mapping of bacterioplankton populations in seawater: field tests across an upwelling plume in Monterey Bay. Aquat Microb Ecol 24: 117-127.

Teske A, Brinkhoff T, Muyzer G, Moser DP, Rethmeier J, Jannasch HW. (2000). Diversity of THIOSULFATEoxidizing bacteria from marine sediments and hydrothermal vents. Appl Environ Microbiol 66: 3125-3133.

Tripp HJ, Kitner JB, Schwalbach MS, Dacey JWH, Wilhelm LJ, Giovannoni SJ. (2008). SAR11 marine bacteria require exogenous reduced sulphur for growth. Nature 452: 741-744.

West NJ, Obernosterer I, Zemb O, Lebaron P. (2008). Major differences of bacterial diversity and activity inside and outside of a natural iron-fertilized phytoplankton bloom in the Southern Ocean. Environ Microbiol 10: 738-756.

Yan S, Fuchs BM, Lenk S, Harder J, Wulf J, Jiao NZ et al. (2009). Biogeography and phylogeny of the NOR5/ OM60 clade of Gammaproteobacteria. Syst Appl Microbiol 32: 124-139.

Yutin N, Suzuki MT, Béjà O. (2005). Novel primers reveal wider diversity among marine aerobic anoxygenic phototrophs. Appl Environ Microbiol 71: 8958-8962.

Zubkov MV, Fuchs BM, Archer SD, Kiene RP, Amann R, Burkill PH. (2001). Linking the composition of bacterioplankton to rapid turnover of dissolved dimethylsulphoniopropionate in an algal bloom in the North Sea. Environ Microbiol 3: 304-311.

Zubkov MV, Fuchs BM, Tarran GA, Burkill PH, Amann R. (2002). Mesoscale distribution of dominant bacterioplankton groups in the northern North Sea in early summer. Aquat Microbiol Ecol 29: 135-144.

Supplementary Information accompanies the paper on The ISME Journal website (http://www.nature.com/ismej) 